\title{
Overexpression of Betaig-h3 gene downregulates integrin $\alpha 5 \beta$ | and suppresses tumorigenicity in radiation-induced tumorigenic human bronchial epithelial cells
}

\author{
YL Zhao', CQ Piao' and TK Hei*,' \\ 'Center for Radiological Research, College of Physicians and Surgeons of Columbia University, VC II-218, 630 West I68th Street, New York, NY I0032, USA
}

Interaction between cell and extracellular matrix plays a crucial role in tumour invasion and metastasis. Using an immortalised human bronchial epithelial (BEP2D) cell model, the study here shows that expression of Betaig-h3 gene, which encodes a secreted adhesion molecule induced by transforming growth factor- $\beta$, is markedly decreased in several independently generated, radiation-induced tumour cell lines (TLI - TL5) relative to parental BEP2D cells. Transfection of Betaig-h3 gene into tumour cells resulted in a significant reduction in tumour growth. While integrin receptor $\alpha 5 \beta$ । was overexpressed in tumour cells, its expression was corrected to the level found in control BEP2D cells after Betaig-h3 transfection. These data suggest that Betaig-h3 gene is involved in tumour progression by regulating integrin receptor $\alpha 5 \beta$ ।. The findings provide strong evidence that the Betaig-h3 gene has tumour suppressor function in human BEP2D cell model and suggest a potential target for interventional therapy.

British Journal of Cancer (2002) 86, 1923 - 1928. doi:I0.1038/sj.bjc.6600304 www.bjcancer.com

(c) 2002 Cancer Research UK

Keywords: Betaig-h3; tumour suppression; human bronchial epithelial cells; integrin receptor

Tumour growth and metastasis is a multistep process involving cell adhesion, extracellular matrix (ECM) degradation and cell migration (Tlsty, 1998). The integrin superfamily consists of a major class of transmembrane glycoproteins that mediate cell-ECM and cell-cell adhesion (Giancotti and Ruoslahti, 1999). Loss or gain of expression of specific integrin has been implicated in malignant transformation, tumour progression and metastasis (Mizejewski, 1999). There is evidence that osteosarcoma cells that overexpress integrin $\alpha 5 \beta 1$ show reduced invasive potential (Giancotti and Ruoslahti, 1990). In contrast, upregulation of $\alpha 5 \beta 1$ has been shown to correlate with invasive phenotype in colon cancer and transitional cell carcinoma (Saito et al, 1996; Gong et al, 1997). Similarly, recent data show that high levels of integrin $\alpha 6$ in breast cancer and $\alpha \mathrm{v} \beta 3$ in melanoma correlate with tumour progression (Mukhopadhyay et al, 1999; Hofmann et al, 2000). Therefore, depending on the cell type and tumour model, expression of various integrin subunits may contribute either positively or negatively to the transformed phenotype.

Betaig-h3 is a secreted protein induced by transforming growth factor- $\beta$ (TGF- $\beta$ ) in human adenocarcinoma cells as well as other human cell types (Skonier et al, 1992). Although transfection of Betaig- $h 3$ gene into $\mathrm{CHO}$ (Chinese Hamster Ovary) fibroblasts markedly reduces their ability to form tumours in nude mice (Skonier et al, 1994), its expression as well as regulation in human tumour has not been examined until now. There is evidence that mutations or altered expression of this gene are involved in corneal dystrophy and osteogenesis in human (Bron, 2000; Kim et al, 2000a). In addition, Betaig-h3 protein is a component of ECM

*Correspondence: Dr TK Hei; E-mail: tkhl@columbia.edu Received I November 200 I; revised 7 March 2002; accepted 2I March 2002 in lung, bladder and skin (LeBaron et al, 1995; Billings et al, 2000a,b), which promotes adhesion and the spreading of dermal fibroblasts in vitro and mediates cell adhesion by interacting with $\alpha 3 \beta 1$ integrin in human corneal epithelial cells (Billings et al, 2000b; Kim et al, 2000b). These data suggest that Betaig-h3 protein is involved in cellular adhesion and imply an important role of this gene in the process of human tumour progression.

Although in vitro transformation studies with human cells are highly desirable in studying the molecular events associated with malignant conversion, such studies, thus far, have not been successful with primary human epithelial cells (Hei et al, 1994). Using papillomavirus-immortalised human bronchial epithelial (BEP2D) cells, we have previously shown that $\alpha$-particles can malignantly transform these cells in a stepwise fashion before they become tumorigenic and metastatic in nude mice. It should be stated that although these cells are immortalised, they do not possess any other transformed phenotypes and only after carcinogen treatment, and extended subculturing, do transformed/tumorigenic phenotypes emerge in a sequential fashion (Hei et al, 1994, 1996). The BEP2D cell model is, therefore, useful in studying the genetic events involved in tumour progression. In the present study, we show that ectopic expression of Betaig- $h 3$ gene in radiation-induced tumour cells significantly suppresses their in vivo tumorigenicity. This finding provides strong evidence that Betaig- $h 3$ has tumour suppressor function in human BEP2D cells.

\section{MATERIALS AND METHODS}

\section{Cell culture}

Tumorigenic BEP2D cells were derived previously from treatment of exponentially growing BEP2D cells with a single 
60 cGy dose of alpha-particles (Hei et al, 1996). Tumours larger than $1 \mathrm{~cm}$ in diameter were resected from nude mice and used to establish independently-generated cell lines (TL1-TL5). The BEP2D cells and tumour cell lines were maintained in serumfree LHC-8 medium supplemented with growth factors as described previously (Hei et al, 1994). Primary human bronchial epithelial (NHBE) cells were purchased from Clonetics (catalogue no: CC-2541) and grown in BEGM medium (Clonetics).

\section{cDNA array and Northern blotting}

cDNA array (Clontech) was hybridised with ${ }^{32} \mathrm{P}$-labelled cDNA probes prepared by reverse transcription using $1 \mu \mathrm{g}$ mRNA from control BEP2D and TL1 tumour cells as described previously (Zhao et al, 2001). The hybridisation signals were analysed by autoradiography and further quantified by phosphorimaging (ImageQuant software). The expression levels of $\beta$-actin and G3PDH housekeeping genes were used as standards for normalising the expression levels of other genes.

For Northern blot, $2.5 \mu \mathrm{g}$ of mRNA was denatured and separated on a $1 \%$ denaturing agarose formaldehyde gel. The mRNAs were then transferred on nylon membrane (Millipore Corp., Bedford) by downward capillary blotting in $20 \times$ SSC $\left(3 \mathrm{M} \mathrm{NaCl}, \quad 0.3 \mathrm{M} \mathrm{Na}_{3}\right.$ Citrate $2 \mathrm{H}_{2} \mathrm{O}, \mathrm{pH} 7.0$ ) followed by UV cross-linking. Specific probe was generated by labelling of PCRamplified cDNA fragments with $\left[\alpha^{32} \mathrm{P}\right] \mathrm{dCTP}$ using random primed DNA labelling kit (Boehringer, Mannheim). The membranes were pre-hybridised for $30 \mathrm{~min}$ and then hybridised with cDNA probe in ExpressHyb TM hybridisation solution (Clontech) for $8-12 \mathrm{~h}$ at $68^{\circ} \mathrm{C}$. The blots were washed twice in $2 \times$ SSC, $0.1 \%$ SDS at room temperature for $15 \mathrm{~min}$ followed by washing twice in $0.2 \times \mathrm{SSC}, 0.1 \%$ SDS at $55^{\circ} \mathrm{C}$ for $15 \mathrm{~min}$. The membranes were exposed to Kodak BioMax film at $-70^{\circ} \mathrm{C}$ for $12-72 \mathrm{~h}$. The band intensities were evaluated by phosphorimaging and normalised to $\beta$-actin expression level.

All probes for Northern blot were acquired by PCR amplified gene fragments using the following primer sets: $\alpha 5$ : 5 '-AGAGCCAAAGTCTGCAGTTG-3'， 5'-CTGGAGGCTTGAGCTGAGCT-3'; $\beta 1: \quad 5^{\prime}$-GTGTTCAGTGCAGAGCCTTCA-3', $5^{\prime}$-CTTCGGATTGA CCACAGTTG- $3^{\prime} ; \beta$-actin: $5^{\prime}$-GTTGCTATCCAGGCTGTGC-3', $5^{\prime}$ GCATCCTGTCGGCAATGC-3'

\section{Cloning and sequencing of Betaig-h3 cDNA}

The first strand cDNA was synthesised from $0.2 \mu \mathrm{g}$ poly $(\mathrm{A})^{+}$RNA isolated from NHBE cells using Superscript II reverse transcriptase and oligo(dT) primer (Gibco). Human Betaig- $h 3$ cDNA was then PCR-amplified using high-fidelity MasterAmp ${ }^{\text {TM }}$ DNA polymerase (Epicenter, Madson, WI, USA) and synthetic primers $\left(5^{\prime}\right.$ GTTAAGCTTGCTTGCCCGTCGGTCGCTAGCT-3'， 5'-GCTCTAGAGCCTCCAAGCCACGTGTAGATGT- $3^{\prime}$ ) that included HindIII and $\mathrm{XbaI}$ restriction enzyme recognition sites. The amplified whole length cDNA was subcloned into the HindIII and XbaI-digested pRc/CMV2 expression vector (Invitrogen). The sequence analysis showed that the protein sequence is $100 \%$ identical with that report in GeneBank (accession no: M77349) with the exception of several modified nucleotide sites such as $698(\mathrm{C} \rightarrow \mathrm{G}), 1667$ $(\mathrm{T} \rightarrow \mathrm{C})$ and $1118(\mathrm{C} \rightarrow \mathrm{T})$

\section{Transfection of TL1 tumour cells with Betaig-h3 cDNA}

TL1 tumour cells were plated at $1.5 \times 10^{6}$ per $60 \mathrm{~mm}$ dish in serum-free LHC-8 medium. When $70-80 \%$ confluent, they were transfected with either pRc/CMV2-Betaig-h3 or $\mathrm{pRc} /$ CMV2 $(2 \mu \mathrm{g} / \mathrm{dish}$ ) for $24 \mathrm{~h}$ using lipofectamin (Gibco) according to the manufacturer's instruction. The cells were split at $1: 10$ and cultured in the medium containing $500 \mu \mathrm{g} \mathrm{ml}^{-1}$ of the G418 (Gibco) for 21 days. Colonies were isolated using cloning ring and maintained in the presence of $300 \mu \mathrm{g} \mathrm{ml}^{-1}$ of $\mathrm{G} 418$.

\section{Immunoprecipitation and Western blotting}

For screening the $\alpha 5$ and $\beta 1$ integrin subunit expression, immunoprecipitations were carried out on surface-biotinylated cells as previously described (Trusolino et al, 1998). For analysis of Betaig-h3 protein expression, conditioned medium was collected from confluent culture and the protein was then concentrated using SP sepharose (Amersham) and eluted using SDS sample buffer by boiling $5 \mathrm{~min}$ (Billings et al, 2000b). Protein concentrations were measured by Bio-Rad DC protein assay kit. Samples containing equal amounts of proteins were then fractionated by SDS-PAGE gel, transferred onto Hybond membrane, and immunoblotted with 1:1000 dilution of anti-Betaig-h3 human polyclonal antibody (kindly provided by Dr Paul C Billings). Peroxidase-conjugated anti-rabbit IgG was used to detect Betaigh3 level by ECL procedures.

\section{In vitro growth rate}

Growth curves of TL1 and Betaig-h3-transfected tumour cells were performed by plating $5 \times 10^{4}$ cells into $25 \mathrm{~cm}^{2}$ flask. Cell numbers were determined using Coulter Counter. The results at each time point were the mean value of eight cultures from two independent experiments.

\section{Anchorage-independence growth and tumorigenicity in nude mice}

Anchorage-independence assays were performed by plating the Betaig-h3-transfected and control BEP2D cells in $0.35 \%$ agar on the layer of $0.7 \%$ agar. Colonies $\geqslant 10$ cells in number were counted after 4 weeks. Tumorigenicity assay was performed as described previously (Hei et al, 1994). Briefly, Betaig-h3- or empty vectortransfected tumour cells were injected subcutaneously into nude mice at the left flanks. Tumours were palpated and measured with calipers and tumour volume calculated as (longest diameter $\times$ $\left.(\text { shortest diameter })^{2}\right) \times 0.5$. Control animals were inoculated with either control BEP2D cells or with radiation-induced TL1 tumour cells. For each cell line, two independent experiments were performed.

\section{RESULTS}

\section{Betaig-h3 is downregulated in radiation-induced tumour cell lines}

Tumorigenic BEP2D cells were established by exposing the nontumorigenic, immortalised parental cells to a single $60 \mathrm{cGy}$ dose of $\alpha$-particles as described (Hei et al, 1996). A series of primary and secondary tumour cell lines (TL1-TL5) were established from tumour nodules developed in nude mice. By using cDNA array techniques, a series of genes were identified that were differentially expressed in radiation-induced tumour cells relative to parental BEP2D cells (Zhao et al, 2001). Among these genes, Betaig- $h 3$ expression was markedly decreased in tumour cells (Figure 1A). The result was further confirmed by Northern blot using mRNAs obtained from different passages of transformed cells and five tumour cell lines (Figure 1B). In early-passaged cells (1 week after radiation), no change in Betaig- $h 3$ expression was found when compared with control BEP2D cells. However, the expression of Betaig-h3 was downregulated by 2.4 -fold in late-passaged cells (just before inoculating into nude mice) and between 7.5-9-fold in all five tumour cell lines examined. These results indicate that decreased expression of Betaig-h3 gene might be related to the acquisition of malignant phenotype in BEP2D cells. 
A
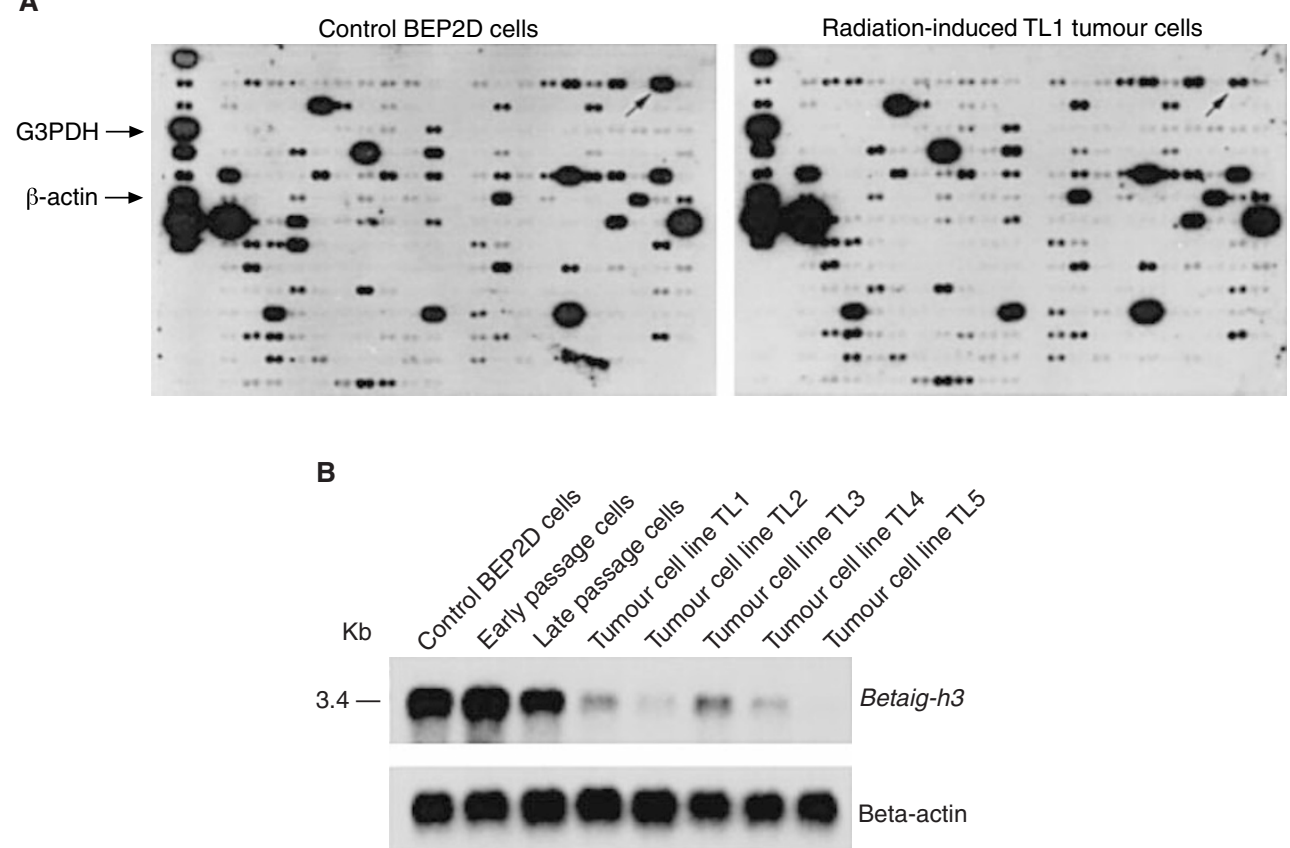

Figure I Differential expression of Betaig-h3 gene in control BEP2D and radiation-induced tumour cells. (A) Human cytokine/receptor array results (Clontech Catalogue no: $7744-1$ ). Arrows indicate the cDNA spots of Betaig-h3 on the membrane. (B) Northern blot analysis of Betaig-h3 gene in control BEP2D cells, early passage cells (I week post radiation), late passage cells (just before inoculation into nude mice) and five tumour cell lines (TL I - TL5). The blots were hybridised to ${ }^{32}$ P-labelled Betaig-h3 cDNA probes. After stripping, the membranes were rehybridised to human $\beta$-actin probe.

\section{Overexpression of Betaig-h3 gene in tumour cells suppresses their colony-forming efficiency in soft agar and tumorigenicity in nude mice}

To examine the significance of Betaig-h3 downregulation in malignant conversion, we recovered the expression of Betaig- $h 3$ gene in a representative tumour cell line (TL1) with pRc/CMV2-Betaigh3 vector. Two G418-resistant colonies (TL1-clones 18 and TL1-clone 28) that expressed different levels of Betaig-h3 were chosen for further studies. From the Northern and Western blot results (Figure 2A), the parental TL1 and TL1-pRc/CMV2 cells (vector control) expressed similar levels of Betaig-h3, which were lower than control BEP2D cells. After Betaig- $h 3$ transfection, the expression of this gene in TL1-clone 18 was recovered to a level similar to that of control BEP2D cells, whereas TL1-clone 28 had a four-fold higher expression level. Expression of the Betaig-h3 gene in primary human bronchial epithelial (NHBE) cells and control BEP2D cells, on the other hand, was similar both at the mRNA and protein levels (Figure 2A).

TL1-clone 18 and TL1-clone 28 cells grew much slower and showed lower saturation density than parental TL1 tumour cells (Figure 2B). The doubling time of cells transfected with the empty vector was $32 \mathrm{~h}$, which was similar to that of TL1 tumour cells. In contrast, clone 18 and 28 cell lines grew slower than TL1, with doubling times of about $55 \mathrm{~h}$. We also checked their colony-forming efficiency in soft agar (Table 1). The result showed that there was no significant difference between parental TL1 and TL1-pRc/CMV2 cells $(2.39$ and $2.28 \%$, respectively with $P>0.05)$. However, TL1-clone 18 and TL1-clone 28 cells resulted in a significantly lower ability of anchorage independent growth with colony-forming efficiency in agar of 0.29 and $0.34 \%$, respectively $(P<0.01)$.

To determine whether ectopic expression of the Betaig- $h 3$ gene suppresses tumour formation in vivo, $5 \times 10^{6}$ of each of the following cell types were subcutaneously injected into nude mice: control BEP2D cells, TL1 tumour cells, TL1-pRc/CMV2 and
Table I Suppression of anchorage-independent growth and tumorigenicity by Betaig-h3 gene

\begin{tabular}{|c|c|c|c|}
\hline Cell type & $\begin{array}{l}\text { CFE in soft } \\
\text { agar }(\%)^{b}\end{array}$ & $\begin{array}{l}\text { Tumours/ } \\
\text { total mice }\end{array}$ & $\begin{array}{l}\text { Tumour volume at } \\
4 \text { weeks }\left(\mathrm{mm}^{3}\right)\end{array}$ \\
\hline BEP2D cells & 0.02 & $0 / 8$ & - \\
\hline TLI tumour cells & $2.39 \pm 0.29$ & $8 / 8$ & $1021.8 \pm 330.7$ \\
\hline TLI-pRc/CMV2 & $2.28+0.37$ & $8 / 8$ & $970.6+295.6$ \\
\hline TLI-Betaig-h3 clone 18 & $0.29 \pm 0.05^{\mathrm{a}}$ & $4 / 8$ & $86.7 \pm 32.3^{\mathrm{a}}$ \\
\hline TLI-Betaig-h3 clone 28 & $0.34 \pm 0.07^{\mathrm{a}}$ & $5 / 8$ & \\
\hline
\end{tabular}

The colonies in soft agar were counted and tumour volumes were measured as described in Materials and Methods. ${ }^{a} p<0.01$, compared with parental tumour cells. ${ }^{\mathrm{C}} \mathrm{CFE}$, Colony Forming Efficiency.

Betaig-h3-transfected cells (clone 18 and 28). The tumour volumes were measured weekly during the experiments. As shown in Table 1 , no tumours (zero out of eight mice) were found in parental BEP2D cells after monitoring for more than 20 weeks. However, eight out of eight mice that were injected with either TL1 or TL1-pRc/CMV2 tumour cells developed progressively growing tumours with average volumes of $1021.8 \pm 330.7 \mathrm{~mm}^{3}$ and $970.6 \pm 295.6 \mathrm{~mm}^{3}$, respectively. In contrast, four out of eight mice with TL1-clone 18 and five out of eight mice with TL1-clone 28 cells formed only small nodules. The volume, which averaged $86.7 \pm 32.3 \mathrm{~mm}^{3}$, was significantly smaller than that of parental TL1 tumour cells $(P<0.01)$. Meanwhile, tumour growth was significantly suppressed in tumour cells after Betaig- $h 3$ transfection (Figure 2C).

\section{Betaig-h3 gene is related to the expression level of integrin} receptor $\alpha 5 \beta 1$

Previous studies have suggested that Betaig-h3 protein affect cellECM interaction through regulation of integrin receptor (LeBaron et al, 1995; Billings et al, 2000a,b). Using cDNA array, it was found 
A

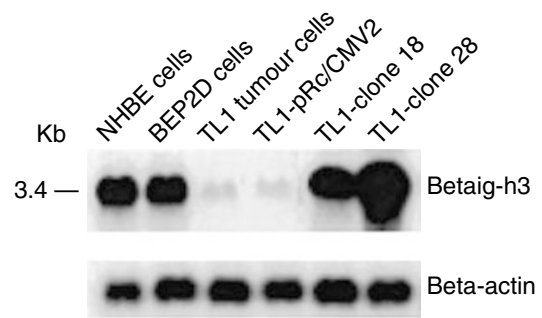

IB: Betaig-h3

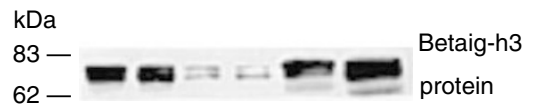

B

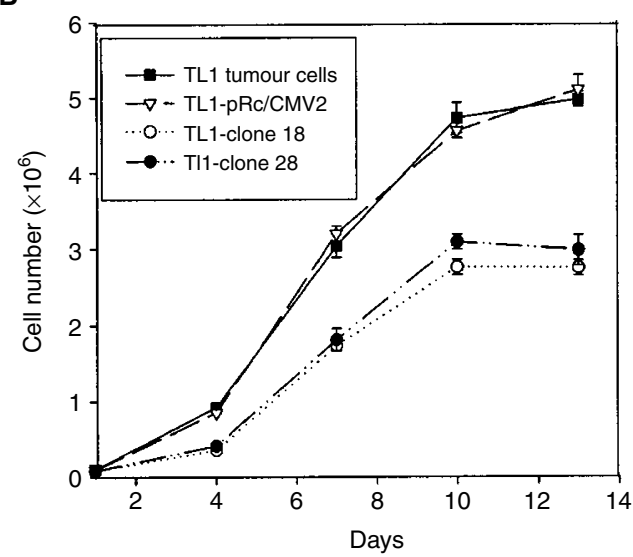

C

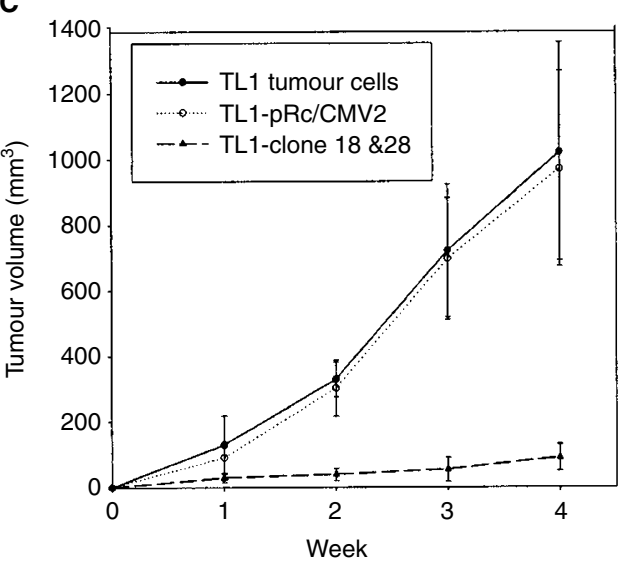

Figure 2 (A) mRNA and protein levels of Betaig-h3 gene determined by Northern blot and immunoblotting (IB) in normal NHBE, control BEP2D, $\mathrm{TLI}$ and Betaig-h3-transfected tumour cells. (B) In vitro growth rate of parental TLI and Betaig-h3-transfected tumour cells. Data represent mean \pm s.d. of eight culture flasks from two independent experiments. (C) Inhibition of tumour growth by Betaig-h3 transfection relative to vector alone and parental TLI tumour cells. Results are expressed as the mean \pm s.d. of $8-9$ independent tumours.

that $\alpha 5 \beta 1$ integrin receptor was overexpressed in radiation-induced tumour cells (data not shown). To determine whether the expression of integrin receptor $\alpha 5 \beta 1$ correlated with Betaig- $h 3$ gene expression, we checked its mRNA and protein levels in Betaig- $h 3$ transfected tumour cells. As shown in Figure 3, expression of $\alpha 5$ and $\beta 1$ subunits was five- and three-fold higher, respectively, in parental TL1 and TL1-pRc/CMV2 cells than in control BEP2D
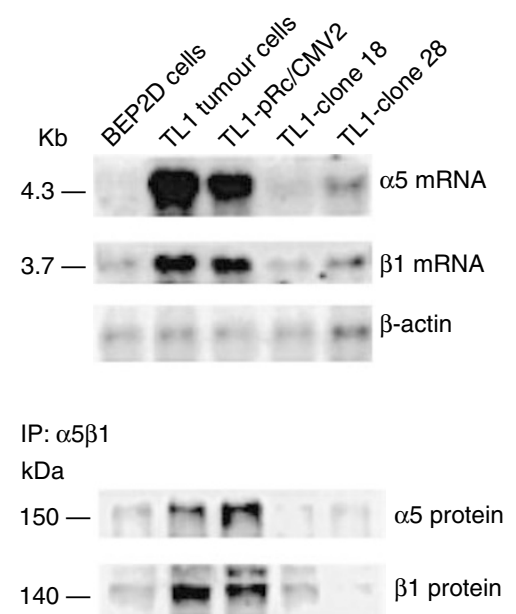

Figure 3 mRNA and protein levels of $\alpha 5 \beta \mid$ determined by Northern blot and immunoprecipitation (IP) in TLI and Betaig-h3-transfected tumour cells.

cells. However, after transfecting Betaig-h3 gene into TL1 tumour cells, expression of $\alpha 5 \beta 1$ integrin (clone 18 and 28 cells) decreased to level of control BEP2D cells. This data were further confirmed by immunoprecipitation using monoclonal antibody for $\alpha 5$ and $\beta 1$. We further checked the mRNA expression of integrin subunits $\alpha 1-\alpha 4, \alpha 6, \alpha \mathrm{v}$ and $\beta 2-\beta 3$. No significant changes in their expression were found among control BEP2D, TL1 tumour cells and Betaigh3-transfected TL1 tumour cells (data not shown).

\section{DISCUSSION}

In an attempt to identify genes involved in the progression of lung carcinoma, cDNA arrays were used to screen differentially expressed genes between control BEP2D and radiation-induced tumour cells. Altered expression of a series of genes that controlled cellular growth and differentiation between these two cell models was found (Zhao et al, 2001), with Betaig-h3 gene notably downregulated in tumour cells, a finding that was further confirmed in five tumour cell lines by Northern blot. Previous studies have shown that Betaig- $h 3$ gene is significantly reduced in embryonal rhabdomyosarcoma cell lines and mesenchymal tumours (Genini et al, 1996; Schenker and Trueb, 1998), suggesting that Betaig-h3 may have an important role in human cancer. Although overexpression of this gene in $\mathrm{CHO}$ fibroblast cells leads to a marked decrease in their ability to form tumour in nude mice (Skonier et al, 1994), little is known about its regulation in tumour progression of human tissues. In this study, we provide evidence that ectopic expression of Betaig-h3 in TL1 tumour cells significantly inhibits colony-forming efficiency in soft agar, and tumour growth in nude mice relative to parental tumour cells. This is the first evidence that Betaig-h3 gene has tumour suppressor function in a human epithelium-derived tumour model.

Betaig- $h 3$ is a secreted protein that promotes the adhesion of dermal fibroblasts and corneal epithelial cells (LeBaron et al, 1995; Billings et al, 2000a,b;). These findings imply that Betaigh3 gene affects cell-ECM interaction by regulating integrin receptors. This study confirms that acquisition of tumorigenic phenotype of BEP2D cells is accompanied by an increased expression of $\alpha 5 \beta 1$ integrin receptor at both the mRNA and protein levels. Ectopic expression of Betaig-h3 gene in tumorigenic cells (TL1) led to downregulation of integrin and suppression of tumorigenicity. The data suggest that Betaig-h3 gene is involved in the tumorigenic process by regulating $\alpha 5 \beta 1$ expression. The observation is consistent with other reports that $\alpha 5 \beta 1$, while 
undetectable in normal lung epithelial, is significantly elevated in SV40 large T-transformed human bronchial epithelial cells (Albelda and Buck, 1990; Schiller and Bittner, 1995). In non-small lung carcinoma cells, higher levels of $\alpha 5 \beta 1$ expression represents a negative prognostic factor (Adachi et al, 2000). Similar results have also been shown with other human tissues that high levels of $\alpha 5 \beta 1$ integrin is associated with more malignant phenotype in melanoma, transitional and colon cell carcinomas (Saito et al, 1996; Gong et al, 1997; Beliveau et al, 2000). The $\alpha 5 \beta 1$ integrin favours cell survival and protects cells from apoptosis in vitro via upregulation of anti-apoptotic Bcl-2, whereas resistance to apoptosis is a feature of many malignant cells (Zhang et al, 1995). These data, together with our results, suggest a key role for $\alpha 5 \beta 1$ overexpression in tumorigenicity of human bronchial epithelial cells. Although there is evidence that the Betaig-h3 protein mediates cell adhesion by interacting with $\alpha 3 \beta 1$ (Kim et al, $2000 \mathrm{~b})$, integrins are expressed in a cell-type- and stage-specific manner (Ruoslahti, 1999). Examples of cell-type-specific integrins include $\alpha \mathrm{II} \beta 3$ in platelets and $\alpha 6 \beta 4$ in epithelial cells. One group of integrins is associated with migration and proliferation in various types of cells. These 'emergency integrins' which include $\alpha 5 \beta 1, \alpha \mathrm{v} \beta 3$, and $\alpha \mathrm{v} \beta 6$ (Sheppard, 1996) are particularly important in cancer. However, no differential expression of $\alpha 1-\alpha 4, \alpha 6, \alpha \mathrm{v}$ and $\beta 2-\beta 3$ integrin subunits was found between Betaig-h3 transfected and parental TL1 tumour cells. The data suggest that Betaig-h3 gene is involved in tumour progression of human bronchial epithelial cell model by regulating integrin receptor $\alpha 5 \beta 1$.

\section{REFERENCES}

Adachi M, Taki T, Higashiyama M, Kohno N, Inufusa H, Miyake M (2000) Significance of integrin alpha5 gene expression as a prognostic factor in node-negative non-small cell lung cancer. Clin Cancer Res 6(1): 96-101

Albelda SM, Buck CA (1990) Integrins and other cell adhesion molecules. FASEB J 4(11): 2868-2880

Beliveau A, Berube M, Rousseau A, Pelletier G, Guerin SL (2000) Expression of integrin alpha5betal and MMPs associated with epithelioid morphology and malignancy of uveal melanoma. Invest Ophthalmol Vis Sci 41(8): $2363-2372$

Billings PC, Herrick DJ, Howard PS, Kucich U, Engelsberg BN, Rosenbloom J (2000a) Expression of Betaig- $h 3$ by human bronchial smooth muscle cells: localization to the extracellular matrix and nucleus. Am J Respir Cell Mol Biol 22(3): $352-359$

Billings PC, Herrick DJ, Kucich U, Engelsberg BN, Abrams WR, Macarak EJ, Rosenbloom J, Howard PS (2000b) Extracellular matrix and nuclear localization of betaig-h3 in human bladder smooth muscle and fibroblast cells. J Cell Biochem 79(2): 261-273

Brezinova J, Zemanova Z, Cermak J, Michalova K (2000) Fluorescence in situ hybridization confirmation of $5 \mathrm{q}$ deletions in patients with hematological malignancies. Cancer Genet Cytogenet 117(1): 45-49

Bron AJ (2000) Genetics of the corneal dystrophies: what we have learned in the past twenty-five years. Cornea 19(5): 699-711

Genini M, Schwalbe P, Scholl FA, Schafer BW (1996) Isolation of genes differentially expressed in human primary myoblasts and embryonal rhabdomyosarcoma. Int J Cancer 66(4): 571-577

Giancotti FG, Ruoslahti E (1999) Integrin signaling. Science 285: 1028 - 1032

Giancotti FG, Ruoslahti E (1990) Elevated levels of the alpha 5 beta 1 fibronectin receptor suppress the transformed phenotype of Chinese hamster ovary cells. Cell 60(5): $849-859$

Gong J, Wang D, Sun L, Zborowska E, Willson JK, Brattain MG (1997) Role of alpha 5 beta 1 integrin in determining malignant properties of colon carcinoma cells. Cell Growth Differ 8(1): 83-90

Hart IR, Saini A (1992) Biology of tumor metastasis. Lancet 339: 1453 - 1457

Hei TK, Piao CQ, Willey JC, Thomas S, Hall EJ (1994) Malignant transformation of human bronchial epithelial cells by radon-simulated alphaparticles. Carciongenesis 15(3): $431-437$

Hei TK, Piao CQ, Han E, Sutter T, Willy JC (1996) Radon-induced neoplastic transformation of human bronchial epithelial cells. Radiat Oncol Invest 3: $398-403$
Altered cell-matrix interaction is an essential prerequisite step in the invasive and metastatic cascade (Hart and Saini, 1992). Our finding that normal NHBE and immortalised BEP2D cells exhibit similar levels of Betaig-h3 expression suggests that loss of its expression occur during late stage of tumour progression. Previous data show that chromosome 5q31, where Betaig- $h 3$ gene has been regionally mapped to, is often deleted in leukaemias, myelodysplastic syndromes and many human cancer such as renal cell, oesophageal and lung carcinomas (Peralta et al, 1998; Wu et al, 1998; Brezinova et al, 2000). These findings suggest that deletion of Betaig-h3 gene is a frequent event in human cancer. The question of whether reexpression of Betaig- $h 3$ gene in human tumour cell lines may result in suppression of tumorigenicity is currently under investigation. Our present finding suggest that Betaig- $h 3$ gene could be a novel diagnostic marker of tumour metastasis and a potential target for cancer therapy.

\section{ACKNOWLEDGEMENTS}

The authors thank Dr Paul C Billings for kindly providing antiBetaigh3 antibody, and Drs Vicente Notario and Takaaki Sato for helpful discussions. Work supported in part by RSNA grant SD0133 and National Institute of Health grants CA49062 \& ES07890.

Hofmann UB, Westphal JR, Waas ET, Becker JC, Ruiter DJ, van Muijen GN (2000) Coexpression of integrin alphavbeta3 and matrix metallo-proteinase-2 (MMP-2) coincides with MMP-2 activation: correlation with melanoma progression. J Invest Dermatol 115(4): 625-632

Kim JE, Kim EH, Han EH, Park RW, Park IH, Jun SH, Kim JC, Young MF, Kim IS (2000a) TGF-beta-inducible cell adhesion molecule, betaig-h3, is downregulated in melorheostosis and involved in osteogenesis. J Cell Biochem 77(2): 169-178

Kim JE, Kim SJ, Lee BH, Park RW, Kim KS, Kim IS (2000b) Identification of motifs for cell adhesion within the repeated domains of transforming growth factor-beta-induced gene, betaig-h3. J Biol Chem 275(40): 30907-30915

LeBaron RG, Bezverkov KI, Zimber MP, Pavelec R, Skonier J, Purchio AF (1995) Beta IG-H3, a novel secretory protein inducible by transforming growth factor-beta, is present in normal skin and promotes the adhesion and spreading of dermal fibroblasts in vitro. J Invest Dermatol 104(5): $844-849$

Mizejewski GJ (1999) Role of integrins in cancer: survey of expression patterns. Proc Soc Exp Biol Med 222(2): 124-138

Mukhopadhyay R, Theriault RL, Price JE (1999) Increased levels of alpha6 integrins are associated with the metastatic phenotype of human breast cancer cells. Clin Exp Metastasis 17(4): 325-332

Peralta RC, Casson AG, Wang RN, Keshavjee S, Redston M, Bapat B (1998) Distinct regions of frequent loss of heterozygosity of chromosome $5 \mathrm{p}$ and $5 \mathrm{q}$ in human esophageal cancer. Int J Cancer 78(5): 600-605

Ruoslahti E (1999) Fibronectin and its integrin receptors in cancer. Advances in Cancer Research 76: $1-20$

Saito T, Kimura M, Kawasaki T, Sato S, Tomita Y (1996) Correlation between integrin alpha 5 expression and the malignant phenotype of transitional cell carcinoma. Br J Cancer 73(3): 327-331

Schenker T, Trueb B (1998) Down-regulated proteins of mesenchymal tumor cells. Exp Cell Res 239(1): 161-168

Schiller JH, Bittner G (1995) Loss of the tumorigenic phenotype with in vitro, but not in vivo, passaging of a novel series of human bronchial epithelial cell lines: possible role of an alpha 5/beta 1-integrin-fibronectin interaction. Cancer Res 55(24): 6215-6221 
Skonier J, Neubauer M, Madisen L, Bennett K, Plowman GD, Purchio AF (1992) cDNA cloning and sequence analysis of beta Betaig-h3, a novel gene induced in a human adenocarcinoma cell line after treatment with transforming growth factor-beta. DNA Cell Biol 11(7): 511-522

Skonier J, Bennett K, Rothwell V, Kosowski S, Plowman G, Wallace P, Edelhoff S, Disteche C, Neubauer M, Marquardt H (1994) Betaig-h3: a transforming growth factor-beta-responsive gene encoding a secreted protein that inhibits cell attachment in vitro and suppresses the growth of CHO cells in nude mice. DNA Cell Biol 13(6): 571-584

Sheppard D (1996) Epithelial integrins. Bioessays 18(8): 655-660

Tlsty TD (1998) Cell-adhesion-dependent influences on genomic instability and carcinogenesis. Curr Opin Cell Biol 10(5): 647-653

Trusolino L, Serini G, Cecchini G, Besati C, Ambesi-Impiombato FS, Marchisio PC, De Filippi R (1998) Growth factor-dependent activation of alphavbeta3 integrin in normal epithelial cells: implications for tumor invasion. J Cell Biol 142(4): 1145-1156

Wu X, Zhao Y, Kemp BL, Amos CI, Siciliano MJ, Spitz MR (1998) Chromosome 5 aberrations and genetic predisposition to lung cancer. Int J Cancer 79(5): $490-493$

Zhao YL, Piao CQ, Hall EJ, Hei TK (2001) Mechanisms of radiation-induced neoplastic transformation of human bronchial epithelial cells. Radiat Res 155(1 Pt2): 230-234

Zhang Z, Vuori K, Reed JC, Ruoslahti E (1995) The alpha 5 beta 1 integrin supports survival of cells on fibronectin and up-regulates Bcl-2 expression. Proc Natl Acad Sci USA 92(13): 6161-6165 